Article

\title{
Exploring Mediating Factors between Agricultural Training and Farmers' Adoption of Drip Fertigation System: Evidence from Banana Farmers in China
}

\author{
Qian Yang (D), Yueji Zhu * and Fang Wang
}

check for updates

Citation: Yang, Q.; Zhu, Y.; Wang, F. Exploring Mediating Factors between Agricultural Training and Farmers' Adoption of Drip Fertigation System: Evidence from Banana Farmers in China. Water 2021, 13, 1364. https:// doi.org/10.3390/w13101364

Academic Editor: Hirotaka Saito

Received: 28 March 2021

Accepted: 12 May 2021

Published: 14 May 2021

Publisher's Note: MDPI stays neutral with regard to jurisdictional claims in published maps and institutional affiliations.

Copyright: (c) 2021 by the authors. Licensee MDPI, Basel, Switzerland. This article is an open access article distributed under the terms and conditions of the Creative Commons Attribution (CC BY) license (https:// creativecommons.org/licenses/by/ $4.0 /)$.
Department of Agriculture \& Forestry Economics and Management, Management School, Hainan University, Haikou 570228, China; ruyi126@126.com (Q.Y.); 992018@hainanu.edu.cn (F.W.)

* Correspondence: zhuyueji@126.com

Abstract: (1) Background: Rare empirical evidence has been explored concerning the ways in which training affects farmers' adoption of resource conservation technology in agricultural production. This study attempts to analyze the role of three factors, including farmers' absorptive capacity, social interaction and active learning, in bridging agricultural training and farmers' adoption of the drip fertigation system (DFS), based on the primary data of 632 banana farmers collected in China. (2) Methods: A mediation model is used to estimate the role of farmers' absorptive capacity, social interaction and active learning in the relationship between agricultural training and farmers' adoption of the DFS. A treatment effect model (TEM) is employed to address the potential endogeneity problem. (3) Results: The results show that agricultural training has significantly increased farmers' adoption of the DFS in banana cultivation. The mediating effect of the three factors appears statistically significant. Specifically, farmers' active learning contributes to the effect of agricultural training on encouraging their adoption of the DFS by around 60 percent; farmers' absorptive capacity and social interaction contribute about 30 and 10 percent, respectively. This study also find that agricultural training can increase farmers' adoption rate of the DFS by 18.75 percent after the endogeneity problem has been addressed using the treatment effect model (TEM). (4) Conclusions: The findings suggest that agricultural training can promote farmers' adoption of the DFS through improving their absorptive capacity, social interaction and active learning. Understating these mediating factors will enable extension agency to design effective agricultural training programs and better promote resource-conservation technologies in developing countries.

Keywords: agricultural training; technology adoption; active learning; absorptive capacity; social interaction

\section{Introduction}

Agricultural training is a common strategy to promote innovative technologies among farmers in developing countries. Resource-conservation technologies encourage farmers to reduce chemical fertilizers and pesticides in agricultural production. Many developing countries have been aware of the importance of resource-conservation technologies in the development of sustainable agriculture. The arable land area per capita is 0.086 hectares in China, which is far below the world average of 0.192 hectares (World Bank, 2016). Smallscale farmers have to raise agricultural productivity by all means in order to secure the food supply. However, their agricultural productivity is closely associated with the excessive use of chemical fertilizers in agricultural production. According to the FAO, China's chemical fertilizers use in agriculture has been steadily ranked first in the world for the past ten years. The evidence has shown that excessive use of chemical fertilizers leads to soil degradation, environmental pollution, and poor quality of agricultural products [1-3]. Additionally, the use efficiency of chemical fertilizer is very low in agricultural production [4]. The excessive use of chemical fertilizers might seriously hinder the development of sustainable 
agriculture in China. Hence, the Chinese government is making great efforts to introduce new technologies into farming practices to reduce the use of chemical fertilizers and to improve their efficiency.

The development in agriculture can be accelerated through advanced technologies. In order to improve the level of agricultural mechanization and agricultural productivity, various innovative technologies have been designed and tested to fit agricultural practices [5]. Fertigation is the process of applying chemical fertilizers to crops along with the irrigation water. The drip fertigation system (DFS) is the application of fertilizers through a drip irrigation system. It is the most advanced and efficient practice of fertilization watering for many crops [6]. Growing evidence has indicated that the DFS remarkably improves the efficiency of chemical fertilizer and water use, reducing environmental pollution and increasing crop yield and quality [7-10]. For example, Sidhu et al. [9] show that the DFS can save about 50 percent of irrigation water and 20 percent of nitrogen fertilizer in India. In the analysis of greenhouse gas emissions of the DFS, Lv et al. [11] pointed out that the DFS can significantly reduce nitrogen emissions. Other evidence also show that irrigation management techniques may reduce soil $\mathrm{CO}_{2}$ and $\mathrm{N}_{2} \mathrm{O}$ emissions and enhance $\mathrm{C}$ sequestration in soils, and ultimately contribute to the sustainable development of farms [12,13]. Farmers' adoption of the DFS could potentially increase banana yields with less input in production, and lead to the sustainable development of the banana industry and environment protection in China.

Compared to many developed countries, the application and development of the DFS in China are relatively late. This may be related to the way in which the current agricultural innovations are disseminated. China's agricultural extension system faces huge challenges in providing appropriate knowledge to hundreds of millions of farmers, owing to limited budgets and poor performance incentives for extension technicians [14]. The system involves government departments in cooperation with research institutes or agricultural enterprises to promote agricultural technologies to farmers. They have many methods of extending agricultural technology, such as training, field guidance, etc. However, due to the limited human and financial resources, Chinese extension technicians usually select a small number of farmers as the target of technology dissemination. The target farmers are generally better educated and have larger farms in the village. As a result, most farmers may be poorly informed about new agricultural technology. Only a few farmers adopt agricultural technology at the early stage of the extension. The number of cumulative adopters can be described by an S-shaped curve as the technology spreads over several stages, with a few adopters initially, followed by a take-off in the rate of adoption as the opinion leaders decide to use the innovation, and eventually by a slow growth of the rate of adoption as the number of potential adopters remaining decreases [15].

Many studies have attempted to identify the stimuli for farmers' adoption of new agricultural technologies [16-21]. Farmers' characteristics and their family endowments have been widely examined to figure out factors that influence farmers' adoption of agricultural technologies. For example, Coromaldi et al. [22] argued that farmers' use of an innovative technology is closely related to their age, education and land size. Additionally, the studies of the cases in China have shown the importance of farmers' planting experience in promoting the adoption of innovative agricultural technologies $[23,24]$. Family income level is also considered to be an important constraint for farmers to adopt new technologies [25], because of the extra cost incurred for farmers to obtain these technologies. In recent years, off-farm, social networks, technical training, technology cognition, cooperative member and agricultural credit have become the focus of discussion on farmers' agricultural technology adoption in various countries [26-30]. Among the factors, farmers' technology cognition has been identified as a prerequisite for their adoption decisions. For example, Tate et al. [17] found that farmers' cognition of new technology was the most important factor in contributing to farmers' adoption of renewable energy technology. Yigezu et al. [25] also highlight the importance of farmers' first exposure to new technology in their adoption decisions. In China, farmers' cognition of a new agricultural technology 
largely influenced by the information from the government, the market or other farmers in the social networks. The agricultural knowledge disseminated by the government has a high degree of credibility for farmers. The government generally organizes agricultural training to promote an agricultural technology to farmers. The government's support for innovation programs is conducive to the improvement of the competitiveness of a given region [31]. Many researchers have explored the relationship between technology adoption and technical training [27,32]. However, empirical evidence on the impact of agricultural training on technology adoption has been mixed. Some revealed a significantly positive association between formal technical training and farmers' adoption of new agricultural technologies [27,32]. In contrast, the effect of technical training on farmers' technology adoption appeared neutral in some studies [33]. Some scholars argued that the construction of the decision processes in the adoption of innovation is not well understood in the developing countries [34,35]. Given the importance of the DFS adoption in minimizing the use of chemical fertilizers and agricultural water, it is still important to understand the effectiveness of agricultural training in promoting the DFS among farmers in developing countries. An important question of how agricultural training affects farmers' decisions remains a "black box". Understanding the mediating factors is of great significance, as the agricultural policies on extension of the DFS can be improved by better designing agricultural training programs. However, rare studies have been conducted on how agricultural training affects the farmers' adoption of the DFS. This study attempts to fill the research gap.

Firstly, this paper attempts to clarify the role of agricultural training in the banana farmers' adoption of the DFS in China. Understanding the effectiveness of agricultural training for farmers in adopting innovative agricultural technologies can help Chinese governments develop appropriate agricultural training programs to encourage farmers to manage chemical fertilizer inputs in an environmentally friendly manner. Secondly, this paper uses a mediation model to examine how agricultural training affects banana farmers' adoption of the DFS in growing bananas, we analyze the role of farmers' absorptive capacity, social interaction and active learning in the linkage between agricultural training and farmers' adoption of the DFS. Answering this question can bring useful implications for extension workers in their promotion programs of agricultural innovations. Thirdly, we employ a treatment effects model to analyze the marginal effect on farmers' adoption of the DFS when they participate in agricultural training. The treatment effect model can address the potential endogeneity problem associated with the sample, and the results estimated from this model can also provide a more direct understanding of the impact of agricultural training on farmers' adoption of the DFS.

The rest of the paper is organized as follows. The analytical framework is given in Section 2, underlying the mediating role of farmers' absorptive capacity, social interaction and active learning in the connection between agricultural training and the adoption of the DFS by banana farmers. Section 3 presents the background and data for this study, particularly on the development of the banana industry in China. It is followed by a descriptive statistics of the data. Section 4 introduces the methods used in this paper. The empirical results and discussion are shown in Section 5, whilst conclusions and policy implications are drawn in the final section.

\section{Analytical Framework}

\subsection{Agricultural Training and Farmers' Absorptive Capacity}

Agricultural training aims to make farmers aware of the new technology and understand the best practice of the technology. A farmer's perception of an innovative technology may be considered as a prerequisite for his or her adoption decision. If farmers perceive that the new technology is feasible in production practice and could bring economic returns, they have a tendency to adopt the technology. However, farmers in a community usually have formulated particular conventions for farming practice through generations, and sometimes it is difficult to change farmers' mindset of cultivation. The change of farmers' 
perception requires them to have the absorptive capacity of new knowledge. Absorptive capacity may be considered as a routine and process by which farmers acquire, assimilate, and transform external knowledge so that they may exploit it to produce a dynamic capability. Agricultural training is an intervention that could possibly make farmers realize the low efficiency of their conventional agricultural production and the advantages of new agricultural technologies. Generally, the trainers have better knowledge and more experience in agricultural cultivation, and they can easily gain farmers' trust because the local government is often involved. In other words, agricultural training is an effective channel for farmers to acquire new agricultural knowledge [36]. However, different farmers have different absorptive capacities for the agricultural information they acquire. The difference of farmers' absorptive capacities about the "knowledge" of the DFS may lead to differences in their perception of the DFS, hence, affecting their adoption of the DFS. Thus, we suspect that agricultural training may subtly change farmers' absorptive capacity about the "knowledge" of the DFS by comparing the economic benefits, applicability and ease of use of conventional irrigation system and the DFS and influence their adoption decisions on the DFS.

\subsection{Agricultural Training and Farmers' Social Interaction}

At the early stage of agricultural technology diffusion, only a small number of "pioneers" are willing to try the new agricultural technology, while most farmers are in a state of "wait-and-see". During this period, these non-adopters attempt to collect the information and learn about the new agricultural technology from the production practice of adopters, such as operating steps, cost and benefit, etc. Social interaction among farmers can often accelerate the learning process and help to spread ideas about using the new technology. The non-adopters can obtain a preliminary understanding about the new agricultural technology through interactions with the adopters. Agricultural training increases opportunities for farmers' social interactions. If farmers participate in agricultural training, they have more chances to interact with extension workers form the local government, village cadres, and other skilled farmers. Thus, agricultural training can virtually increase the interaction frequency and interaction range of farmers. The social interaction of farmers is related to the acquisition and allocation of agricultural information [37]. To some extent, social interaction is the information transmission medium for farmers in rural areas. There is growing empirical evidence that social networks affect positively the adoption of agricultural innovative technologies $[19,38]$. The role of farmers' social interaction on their agricultural activities is well worth exploring. Information exchange links improved cognition and knowledge for all of the technologies and increased adoption of innovative technologies [39]. Based on the above analysis, we argue that farmers participate in agricultural training can enhance farmers' social interaction and thus increase their adoption of the DFS.

\subsection{Agricultural Training and Farmers' Active Learning}

Only a small group of farmers have the opportunity to take the technical training at the early stage. As the technology is new to ordinary farmers, they have to invest time and energy to understand it by learning. A farmer's decision to adopt a new technology is mediated by learning from others or his own trial [40,41]. If a farmer takes the initiative to learn from others, this will give him priority access to information about new agricultural technologies, thereby accelerating his adoption of new technologies. The use of smart phones may provide a way for farmers to access more agricultural information and trigger them to adopt new technologies. Generally, trainers also suggest farmers subscribe to the channels of particular agricultural websites, e-commerce platforms and agricultural research institutions using their smart phones so as to access useful information about new agricultural technologies, management practices, etc. With the popularization of the Internet in rural China, many village committees have set up communication groups for farmers through social media such as WeChat. Village cadres can send important notices in 
the communication group, and farmers with smart phones may receive information about agricultural training programs in advance, so they may be more likely to participate in the agricultural training. During the agricultural training, the trainers can also organize the trained farmers to establish communication groups by WeChat. It can facilitate information sharing in the group after agricultural training ends. Therefore, agricultural training provides the channel of active learning for farmers and lead to their adoption of the DFS in practice.

\section{Background and Data}

\subsection{Banana Production in China}

China is one of the ancient countries of banana cultivation, and most of the main banana varieties are transmitted from China in the world. Banana is by far the fourth largest production of fruits after apple, citrus, pear in China, and mainly produced in Southern regions due to the favorable climatic conditions. In 2018, China had around 383 thousand hectares of banana harvest area, accounting for almost 6.7 percent of the world's harvest area with a total output of about 11,578 thousand tons (FAO, 2018). As shown in Figure 1, China is the second-largest banana producing country after India. The banana industry is important for China, but its productivity is relatively low compared to other countries. According to FAO, banana yield in China is only 30.21 tons per hectare in 2018, ranking 27 th in the world (FAOSTAT, 2018). Therefore, improving banana productivity in China has become a top priority, and it is also responding to the call for the sustainable development of the banana industry.

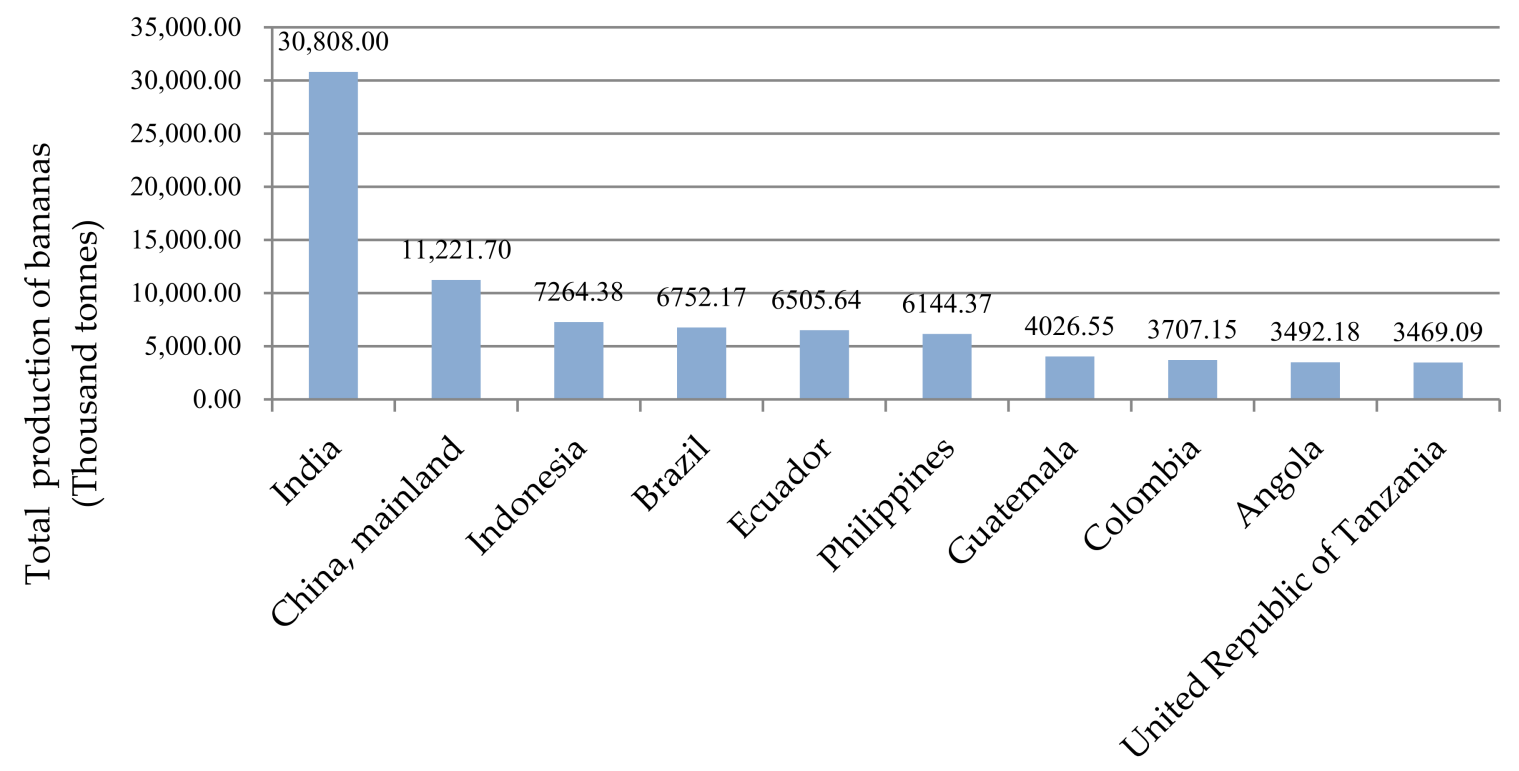

Figure 1. Top 10 banana producing countries by production in 2018. Source: Compiled from the data of FAO.

Three provinces including Guangdong, Hainan and Yunnan are the dominant region for banana production in China. Table 1 shows the planting area, harvest area and production of bananas in three provinces. According to the National Banana Industry Technology System of China, banana planting areas in Guangdong, Hainan and Yunnan were 107, 35 and 93 thousand hectares in 2018, respectively. However, the ratio of harvest area to planting area in Hainan is higher than that in the other two provinces, indicating that the banana industry in Hainan might have comparatively higher productivity. The banana harvest area in Yunnan is 82 thousand hectares, which is 8 thousand hectares less than that in Guangdong, but the banana production in Yunnan is only half of that in Guangdong. This could possibly be as a result of the natural conditions for cultivation, such as the hilly topography in Yunnan province. 
Table 1. Banana production of dominant regions in China (2018).

\begin{tabular}{llll}
\hline Region & $\begin{array}{l}\text { Planting Area } \\
\text { (Thousand Hectares) }\end{array}$ & $\begin{array}{l}\text { Harvest Area } \\
\text { (Thousand Hectares) }\end{array}$ & $\begin{array}{l}\text { Production } \\
\text { (1000 Tons) }\end{array}$ \\
\hline Guangdong & 107 & 90 & 4070.00 \\
Hainan & 35 & 34 & 1210.63 \\
Yunnan & 93 & 82 & 2630.56 \\
\hline
\end{tabular}

Data Sources: The National Banana Industry Technology System of China.

In recent years, China is gradually realizing the importance of the DFS for the transformation of agricultural production in rural areas. The "National Agricultural Water Conservation Outline (2012-2020)" promulgated in 2012 emphasized the necessity to actively promote the DFS in agricultural production. In 2006, the DFS practice was first introduced in China's banana industry, and the first DFS demonstration site was established in Guangdong Province. With the strong support from the local government, the DFS demonstration site timely organized farmers to conduct the training and field-guidance. Those trained local farmers soon realized the economic benefits of the DFS in banana production. In the following years, more and more banana farmers learned and adopted the DFS in their cultivating practice. Agricultural training played an important role in promoting the wide spread of the DFS in China's banana industry.

\subsection{Data Collection}

The data used in this study were collected from July to November 2019 by a household survey of banana farmers in China. The stratified random sampling method was used for selecting respondents. Firstly, three provinces including Guangdong, Hainan and Yunnan were purposefully selected, because they are the dominant regions for bananas production. In 2018, the banana planting areas in Guangdong, Hainan and Yunnan accounted for 67.75 percent of the total banana planting area in China (National Banana Industry Technology System of China). Secondly, fifteen county-level regions with high densities of banana production were selected in three provinces, including five in Guangdong, three in Hainan and ten in Yunnan. Thirdly, we randomly selected two villages from each county. Finally, 15 25 farmers in each village were randomly selected, contributing to a total of 632 representative farmers (the DFS adopters and non-adopters). These farmers are mainly engaged in banana production to support their livelihoods.

Prior to the formal survey, we selected and trained the interviewers, and a pilot survey was conducted to make sure the questionnaire we designed is appropriate for the actual context. During the formal survey, the research group conducted one-on-one and face-toface interviews with farmers. The final dataset we obtained consists of 325 adopters and 307 non-adopters of the DFS in practice.

\subsection{Data Description}

The definition and descriptive statistics of variables are presented in Table 2. The survey showed that 325 banana farmers were using the DFS, with an adoption rate of $51 \%$. The average age of the banana farmers was just over 48 years, and on average they had just 8 years of education. These farmers have been engaged in the banana industry since they were young, many of them have nearly 25 years of banana planting experience. Due to the scarce land resource of each household, their banana farms are often running with very small sizes. The average cultivated banana land of each family is less than 1.94 ha. In addition, each household has an average of just over two agricultural laborers, indicating that their family members generally are reluctant to be engaged in agriculture. For agricultural training, most farmers do not have the experience of attending any training programs, but more than 80 percent of banana farmers argue that agricultural training was "necessary". 
Table 2. The definition and measurement of variables.

\begin{tabular}{|c|c|c|}
\hline Variable & Definition & Mean (S.D.) \\
\hline Adopt & $1=$ If farmers adopt the drip fertigation system (DFS), $0=$ otherwise & $0.51(0.50)$ \\
\hline Training experience & The number of agricultural trainings attended in 2018 & $0.88(1.30)$ \\
\hline Trained & $1=$ If farmers participated in agricultural training in $2018,0=$ otherwise & $0.40(0.49)$ \\
\hline Training needs & $\begin{array}{l}\text { Is it necessary to carry out agricultural training? } \\
\qquad 1=\text { yes, } 0=\text { otherwise }\end{array}$ & $0.81(0.39)$ \\
\hline \multicolumn{3}{|l|}{ Farmers' characteristics } \\
\hline Age & Farmers' age in years & $48.30(9.94)$ \\
\hline Gender & Female $=0 ;$ male $=1$ & $0.83(0.38)$ \\
\hline Education & Number of years of farmers' schooling & $8.04(3.16)$ \\
\hline Planting experience & Years of planting bananas & 25.18(11.79) \\
\hline Off-farm work & $1=$ If farmer participated in off-farm work; $0=$ otherwise & $0.10(0.30)$ \\
\hline Risk preference & $1=$ If farmer prefers to take risks; $0=$ otherwise & $0.14(0.35)$ \\
\hline \multicolumn{3}{|l|}{ Family endowment } \\
\hline Household income & Total annual household income (1000 yuan) & 268.15(749.42) \\
\hline Agricultural laborers & number of family members engaged in agriculture & $2.23(0.94)$ \\
\hline Farm size & Bananas planting area in $\mathrm{mu}$ & $29.17(72.61)$ \\
\hline Agricultural insurance & $1=$ If farmers buy banana insurance; $0=$ otherwise & $0.15(0.36)$ \\
\hline $\begin{array}{l}\text { Access to Internet } \\
\text { Absorptive capacity }\end{array}$ & $1=$ If household has access to the Internet; $0=$ otherwise & $0.60(0.49)$ \\
\hline Perceived applicability & $\begin{array}{l}\text { (score from } 1 \text { to } 5 ; 1=\text { totally inapplicable, } 5=\text { fully applicable) } \\
\text { Applicability of the DFS for the local farms. } \\
\text { (score from } 1 \text { to } 5 ; 1=\text { very complicated, } 5=\text { very easy) }\end{array}$ & $3.31(1.26)$ \\
\hline Perceived ease of use & $\begin{array}{l}\text { Compared with conventional irrigation system, famer perceived ease of } \\
\text { use of the DFS. } \\
\text { (score from } 1 \text { to } 5,1=\text { much less; } 5=\text { much higher) }\end{array}$ & $3.42(1.26)$ \\
\hline Perceived economic benefits & $\begin{array}{c}\text { Compared with conventional irrigation system, the economic benefits of } \\
\text { the DFS. }\end{array}$ & $3.73(0.87)$ \\
\hline Active learning & $\begin{array}{c}1=\text { If farmer takes the initiative to use smart phones to access agricultural } \\
\text { information, } 0=\text { otherwise }\end{array}$ & $0.55(0.50)$ \\
\hline \multicolumn{3}{|c|}{ (25) } \\
\hline Local government & $\begin{array}{l}\text { (score from } 1 \text { to } 5,1=\text { no interaction, } 5=\text { very frequent) } \\
\text { The frequency of interaction with the local government. }\end{array}$ & 2.04(1.11) \\
\hline Village cadres & $\begin{array}{l}\text { (score from } 1 \text { to } 5,1=\text { no interaction, } 5=\text { very frequent) } \\
\text { The frequency of interaction with the village cadres. }\end{array}$ & 2.82(1.19) \\
\hline Small-scale farmers & $\begin{array}{l}\text { (score from } 1 \text { to } 5,1=\text { no interaction, } 5=\text { very frequent) } \\
\text { The frequency of interaction with the small-scale farmers. }\end{array}$ & $4.02(0.90)$ \\
\hline Large-scale farmers & $\begin{array}{l}\text { (score from } 1 \text { to } 5,1=\text { no interaction, } 5=\text { very frequent) } \\
\text { The frequency of interaction with the large-scale farmers. }\end{array}$ & $2.87(1.29)$ \\
\hline Agricultural retailers & $\begin{array}{l}\text { (score from } 1 \text { to } 5,1=\text { no interaction, } 5=\text { very frequent) } \\
\text { The frequency of interaction with the Agricultural retailers. }\end{array}$ & $3.79(1.15)$ \\
\hline Interaction range & Number of farmers closely interacted & $18.60(49.54)$ \\
\hline
\end{tabular}

\subsubsection{Farmers' Absorptive Capacity}

Farmers' absorptive capacity of the DFS in this paper is defined from three aspects. In the survey, we recorded the three types of variables using a five-point Likert scale. The first variable is the perceived applicability of the DFS by banana farmers. This variable is designed to understand farmers' perception of the feasibility of the DFS for banana cultivation. The second variable is the perceived ease of using the DFS. Banana farmers were asked to evaluate the ease of operation of the DFS compared with conventional irrigation system. The perceived economic benefits of the DFS are the third variable to manifest farmers' perception of the economic benefits that the DFS could bring, in contrast to the conventional irrigation system. As shown in Table 2, the surveyed banana farmers generally possess a positive attitude towards the DFS in terms of its application in the three production regions. Additionally, the DFS is easier to operate and brings more economic returns for banana farmers than conventional irrigation techniques. Further, Table 3 presents the mean differences of banana farmers' absorptive capacity regarding 
the DFS for adopters and non-adopters separately. It shows that the adopters and nonadopters are systematically different in terms of their absorptive capacity about the DFS. The adopters obviously have a more positive absorptive capacity about it in these regions. Different from the non-adopters, the adopters are admitting that the DFS is more applicable for the local farms, easier to operate and brings more economic benefits.

Table 3. Mean difference of farmers' absorptive capacity between adopters and non-adopters.

\begin{tabular}{cccc}
\hline Variable & Adopters & Non-Adopters & Diff. \\
\hline Perceived applicability & $3.98(0.05)$ & $2.60(0.07)$ & $1.380^{* * *}$ \\
Perceived ease of use & $4.06(0.05)$ & $2.97(0.06)$ & $1.084^{* * *}$ \\
Perceived economic benefits & $3.94(0.05)$ & $3.51(0.05)$ & $0.360^{* * *}$ \\
\hline
\end{tabular}

Notes: Standard errors are presented in parentheses. ${ }^{* * *} p$ value $<0.01$.

\subsubsection{Social Interaction and Farmers' Active Learning}

A total of 6 questions were used to test the intensity and range of banana farmers' social interaction with different people. These questions were designed according to the understanding of the research context of banana farmers in the pilot survey. Among them, 5 questions include the frequency of farmers' interaction with the local government, village cadres, small-scale farmers, large-scale farmers and agricultural retailers. They were used to test the intensity of the banana farmers' social interactions. In addition, banana farmers were asked to state the number of farmers who closely interacted with them to measure the range of their social interactions. On average, interviewed banana farmers interact frequently with small-scale farmers and agricultural retailers. The interaction range of banana farmers is around 18, indicating that farmers are widely interacted (Table 2).

Smart phones have become increasingly popular among Chinese farmers and are widely used in their daily lives and production work. When a farmer takes the initiative to use smart phones to access agricultural information, and it can be defined as the farmer's active learning. In recent years, it has become the most convenient and popular way for farmers to access agricultural information through smart phones. Among the surveyed banana farmers, more than half of them have the habit of active learning through smart phones in agricultural activities (Table 2).

The mean differences of farmers' social interactions and active learning between adopters and non-adopters are presented in Table 4. It shows that the range of social interactions of adopters is significantly higher than that of non-adopters. With respect to the intensity of social interactions, the adopters interact more frequently with large-scale farmers and agricultural retailers than non-adopters. As for active learning, adopters have more tendency to learn from smart phones than non-adopters. The mean values between the two groups of banana farmers are significantly different (Tables 3 and 4).

Table 4. Mean difference of active learning and social interactions between adopters and non-adopters.

\begin{tabular}{cccc}
\hline Variable & Adopters & Non-Adopters & Diff. \\
\hline Active learning & $0.60(0.49)$ & $0.49(0.50)$ & $0.111^{* * *}$ \\
Local government & $1.96(1.14)$ & $2.13(1.07)$ & $-0.170^{* *}$ \\
Village cadres & $2.87(1.21)$ & $2.78(1.16)$ & 0.096 \\
Small-scale farmers & $4.12(0.89)$ & $3.92(0.89)$ & 0.198 \\
Large-scale farmers & $2.93(1.34)$ & $2.80(1.24)$ & $0.131^{*}$ \\
Agricultural retailers & $3.93(1.09)$ & $3.64(1.21)$ & $0.281^{* * *}$ \\
Interaction range & $22.41(65.21)$ & $14.56(22.96)$ & $7.852^{* * *}$ \\
\hline Notes: Standard errors are presented in parentheses. ${ }^{* * *} p$ value $<0.01,{ }^{* *} p$ value $<0.05,{ }^{*} p$ value $<0.1$.
\end{tabular}




\section{Methodology}

\subsection{Mediation Model}

The mediating effect model is used to examine the influence path of agricultural training on the DFS adoption of banana farmers. This model is often employed to reveal the internal mechanisms in the causal chain [42]. Identifying the process of action between phenomena in empirical research can clarify the complex cause-effect relationship, thus policymakers may adopt more targeted policies based on the direction and strength of the mediating effect [43]. The most common way to test the mediating effect is to stepwise test the regression coefficient $[44,45]$, also known as the test of joint significance in the literature [46]. The mediating effect model can be written as:

$$
\text { Trained }_{i}+e_{1}
$$

where the dependent variable $A d o p t_{i}$ is a binary variable, representing the propensity of banana farmer $i$ 's adoption of the DFS. It refers to farmer $i$ 's status, where Adopt $t_{i}=1$ for adopters and $A$ dopt $_{i}=0$ for non-adopters; Trained $_{i}$ is the independent variable that captures banana farmer $i$ 's participation in agricultural training. If Trained $_{i}=1$, banana farmers participated in agricultural training in 2018; otherwise, Trained $_{i}=0 . \varphi$ is the total effect of the independent variable Trained $_{i}$ on the dependent variable $A d o p t_{i}, e_{1}$ is an error term.

$$
\text { CSS }_{i}=\alpha \text { Trained }_{i}+e_{2}
$$

where $C S S_{i}$ is the mediating variable and represents farmer $i$ 's the absorptive capacity of the DFS, social interaction or active learning in this paper. $\alpha$ is the effect of the independent variable Trained $_{i}$ on the mediating variable $C S S_{i}, e_{2}$ is an error term.

$$
\text { Adopt }_{i}=\varphi^{\prime} \text { Trained }_{i}+\beta \text { CSS }_{i}+\mathrm{e}_{3}
$$

where $\beta$ is the effect of the mediating variable CSS $_{i}$ on the dependent variable Adopt $t_{i}$ after controlling the effect of the independent variable $\operatorname{Trained}_{i} ; \varphi^{\prime}$ is the direct effect of independent variable Trained $_{i}$ on dependent variable Adopt $_{i}$ after controlling the effect of the mediating variable $\operatorname{CSS}_{i}$. If the coefficients $\alpha, \beta$ and $\varphi$ in Equations (1)-(3) are statistically significant, the mediating effect can be considered to be valid. Furthermore, if the coefficient $\varphi^{\prime}$ is significant, the mediating variable $C_{S S}$ is a partially mediating effect, otherwise it is a completely mediating effect.

\subsection{Treatment Effect Model}

The mediating effect model can be used to preliminarily explore the impact of agricultural training on the banana farmers' adoption of the DFS. However, farmers' participation in agricultural training involves a complicated decision-making process that can be affected by many factors. However, the interviewed banana farmers can be simply divided into participators or non-participators. Considering the endogeneity problem that might incur in farmers' participation in agricultural training, the treatment effect model (TEM) is used to overcome the problem. However, this model is appropriate technique only if the dependent variable in the selection equation is binary.

The estimation in the TEM has two stages. The first stage is the regression of the selection equation, which estimates the influencing factors of banana farmers' participation in agricultural training. The choice of whether banana farmer $i$ participates in agricultural training can be expressed as follows:

$$
\text { Trained }_{i}^{*}=Z_{i} \beta+\mu_{i} \text { Trained }_{i}=\left\{\begin{array}{l}
1, \text { Trained }_{i}^{*}>0 \\
0, \text { Trained }_{i}^{*} \leq 0
\end{array}\right.
$$

when Trained $_{i}$ is 1 , it represents banana farmer $i$ participates in agricultural training, otherwise Trained $_{i}=0 . Z_{i}$ represents the farmer $i$ 's basic characteristics, family endowment 
and other factors that affect his/her participation in agricultural training. $\beta$ are unknown parameters to be estimated, and $\mu_{i}$ is the error term.

The second stage is the regression of the result equation, which measures the impact of banana farmers' participation in agricultural training on their adoption of the DFS. The result equation can be specified as follows:

$$
\text { Adopt }_{i}=X_{i} \lambda+\text { Trained }_{i} \alpha+\varepsilon_{i}
$$

where the explained variable $A d o p t_{i}$ represents banana farmers $i$ 's adoption decision of the DFS, $X_{i}$ is a vector of the influencing factors for banana farmer $i$ 's adoption of the DFS, $\lambda$ and $\alpha$ are unknown parameters to be estimated, $\varepsilon_{i}$ is the error term.

\section{Results and Discussion}

\subsection{Impact of Agricultural Training on the Banana Farmers' Adoption of the DFS}

Equation (1) in the mediating effect model was used to examine the impact of agricultural training on the banana farmers' adoption of the DFS. The results are shown in Table 5. As we expected, the first row reports that agricultural training for banana farmers can increase farmers' adoption probability of the DFS with significance at the $1 \%$ level. The results also show that banana farmers' adoption of the DFS was affected by their planting experience, off-farm work, risk preference, agricultural laborers and agricultural insurance (Column 1). The DFS is a resource-saving technology that can replace agricultural laborers. The more agricultural laborers a family has, the more likely it is to exclude the use of the DFS. Farmers also took possible risks into account when making decisions to adopt an innovative agricultural technology in banana production. In the early stage of diffusion of new technologies, innovative farmers have to pay the cost of the technical facilities, and it is uncertain that the technology could bring obvious economic benefits to the farmers. From the perspective of risk preference, farmers with risk-taking tendency may be more willing to adopt the DFS in their farming practice, as proven in this study (row 9). Moreover, farmers who have bought agricultural insurance have less incentive to adopt the DFS. We consider these farmers are more risk averse and do not tend to be the first to adopt an agricultural innovation. In this study, off-farm work has a positive impact on the banana farmers' adoption of the DFS. Only 67 banana farmers have off-farm work experience in the sample, and the duration of off-farm work is less than one year. According to our survey, these farmers are mainly engaged in agriculture, and the short experience of off-farm work can anyhow extend their social interactions. Hence, it would increase the channels for banana farmers to understand the DFS and produce more adopters. In addition, the increased income from off-farm work could encourage farmers to invest more in upgrading agricultural technologies. The results show that farmers' planting experience negatively influences their adoption of the DFS. It is supported by our field research with farmers in these regions. We found that banana farmers with more planting experience believe that they are skilled enough in banana production, and do not easily change their cultivation habits including the use of conventional agricultural techniques.

We conduct a robustness check by replacing the main explanatory variable "Trained" with "Training experience". The results of the robustness check are provided in Column 2. We find that the training experience of farmers has a significant impact on the banana farmers' adoption of the DFS. Most of the estimated coefficients are close to the corresponding estimated results in Column 1. Thus, the results can be seen as reliable. 
Table 5. Impact of agricultural training on the banana farmers' adoption of the DFS.

\begin{tabular}{ccc}
\hline Variable & $\begin{array}{c}\text { Adopt } \\
\mathbf{( 1 )}\end{array}$ & $\begin{array}{c}\text { Adopt } \\
\mathbf{( 2 )}\end{array}$ \\
\hline Trained & $0.726(0.187)^{* * *}$ & \\
Training experience & & $0.180(0.070)^{* * *}$ \\
Age & $0.021(0.014)$ & $0.018(0.014)$ \\
Gender & $-0.209(0.245)$ & $-0.201(0.246)$ \\
Education & $-0.012(0.031)$ & $-0.011(0.031)$ \\
Planting experience & $-0.048(0.012)^{* * *}$ & $-0.046(0.012)^{* * *}$ \\
Off-farm work & $0.797(0.303)^{* * *}$ & $0.860(0.302)^{* * *}$ \\
Risk preference & $0.914(0.292)^{* * *}$ & $0.909(0.286)^{* * *}$ \\
Household income & $-0.089(0.100)$ & $-0.090(0.099)$ \\
Agricultural laborers & $-0.196(0.113)^{*}$ & $-0.187(0.110)^{*}$ \\
Farm size & $0.002(0.003)$ & $0.003(0.002)$ \\
Agricultural insurance & $-1.137(0.288)^{* * *}$ & $-1.116(0.287)^{* * *}$ \\
Constant & $1.632(1.231)$ & $1.778(1.234)$ \\
Pseudo R-square & 0.093 & 0.088 \\
Prob $>$ chi & 0.000 & 0.000 \\
Observations & 632 & 632 \\
\hline
\end{tabular}

Notes: Standard errors are presented in parentheses. ${ }^{* * *} p$ value $<0.01,{ }^{*} p$ value $<0.1$

\subsection{Absorptive Capacity and the Banana Farmers' Adoption of the DFS}

We verify the mediating effect of farmers' absorptive capacity in the relationship between agricultural training and the banana farmers' adoption of the DFS, using a linear regression model. Firstly, Equation (2) was used to examine the impact of agricultural training on the banana farmers' absorptive capacity. The results show that agricultural training can improve banana farmers' absorptive capacity in terms of perceived applicability and the perceived ease of using the DFS (Columns 1-2 in Table 6). The coefficient of "perceived economic benefits" is positive but not statistically significant, implying that the impact of agricultural training on the banana farmers' perceived economic benefits of the DFS is hardly detectable (Column 3). The possible reason is that it has been already the late phase of the DFS extension, and banana farmers generally believe that the DFS can bring economic benefits, so there is no significant difference between the two groups.

Table 6. The mediating effect of farmers' absorptive capacity.

\begin{tabular}{|c|c|c|c|c|}
\hline Variable & Perceived Applicability & $\begin{array}{l}\text { Perceived Ease of Use } \\
(2)\end{array}$ & $\begin{array}{l}\text { Perceived Economic Benefits } \\
\text { (3) }\end{array}$ & $\underset{(4)}{\operatorname{Adopt}}$ \\
\hline Trained & $0.260(0.105) * *$ & $0.259(0.097) * * *$ & $0.041(0.069)$ & $0.467(0.232) * *$ \\
\hline Perceived applicability & & & & $0.905(0.119) * * *$ \\
\hline Perceived ease of use & & & & $0.856(0.130) * * *$ \\
\hline Perceived economic benefits & & & & $0.408(0.150) * * *$ \\
\hline Age & $0.017(0.007) * *$ & $0.041(0.007) * * *$ & $0.013(0.005) * * *$ & $-0.014(0.016)$ \\
\hline Gender & $-0.273(0.139) * *$ & $-0.164(0.134)$ & $-0.123(0.095)$ & $0.036(0.306)$ \\
\hline Education & $0.007(0.018)$ & $0.019(0.018)$ & $0.039(0.015)^{* * *}$ & $-0.064(0.041)$ \\
\hline Planting experience & $-0.024(0.006) * * *$ & $-0.037(0.006) * * *$ & $-0.009(0.004) * *$ & $-0.017(0.014)$ \\
\hline Off-farm work & $0.460(0.168)^{* * *}$ & $0.309(0.136) * *$ & $-0.281(0.129) * *$ & $0.767(0.380)^{* *}$ \\
\hline Risk preference & $0.134(0.146)$ & $0.259(0.133) *$ & $0.157(0.096) *$ & $1.023(0.340) * * *$ \\
\hline Household income & $0.042(0.052)$ & $0.107(0.048) * *$ & $-0.016(0.036)$ & $-0.276(0.118) * *$ \\
\hline Agricultural laborers & $0.008(0.051)$ & $-0.045(0.048)$ & $-0.008(0.038)$ & $-0.208(0.114) *$ \\
\hline Farm size & $-0.001(0.001)$ & $-0.001(0.001)^{* *}$ & $-0.001(0.006)$ & $0.004(0.002) * *$ \\
\hline Agricultural Insurance & $-0.456(0.156) * * *$ & $-0.318(0.118) * * *$ & $0.045(0.085)$ & $-0.934(0.340) * * *$ \\
\hline Active learning & $0.326(0.107) * * *$ & $0.460(0.109) * * *$ & $0.218(0.080) * * *$ & \\
\hline Interaction range & $0.002(0.001)^{* *}$ & $0.001(0.001)$ & $-0.002(0.001) *$ & \\
\hline Constant & $2.468(0.655) * * *$ & $0.896(0.604)$ & $3.203(0.458) * * *$ & $-2.701(1.597) *$ \\
\hline Pseudo R-square & 0.098 & 0.152 & 0.084 & 0.387 \\
\hline Prob $>\mathrm{chi}^{2}$ & 0.000 & 0.000 & 0.000 & 0.000 \\
\hline Observations & 632 & 632 & 632 & 632 \\
\hline
\end{tabular}


We construct a regression model using agricultural training as a control variable, the banana farmers' adoption decisions as the dependent variable, and farmers' absorptive capacity as the independent variable to test the Equation (3) in the mediating effect model. The regression results are shown in Table 6, Column 4, and farmers' absorptive capacity of the DFS play a positive and significant role in the banana farmers' adoption of the DFS. The farmers' perceived economic benefits of the DFS only directly affect their adoption of the DFS. The coefficient "perceived applicability" and "perceived ease of use" is statistically significant, so farmers' perceived applicability and perceived ease of using the DFS partially mediate the impact of agricultural training on their adoption of the DFS. The mediating effect of perceived applicability accounts for the proportion of the total effect is about 0.324 . It can be said that about 32.4 percent of the impact of agricultural training on banana farmers' adoption decisions of the DFS is achieved through the mediating effect of the "perceived applicability". Similarly, we can know that about 30.5 percent of the effect of agricultural training on banana farmers' adoption decisions of the DFS is due to the mediating effect of the "perceived ease of use". Farmers could improve their absorptive capacity with the respect of perceived applicability and the perceived ease of use about the DFS through agricultural training, their adoption rate was increased.

\subsection{Social Interaction and the Banana Farmers' Adoption of the DFS}

The same method as above has been conducted to explore the mediating role of "social interaction" between agricultural training and farmers" adoption of the DFS. Firstly, Equation (2) is used to explain the relationship between agricultural training and the social interaction of banana farmers. The results show that agricultural training can increase the frequency of interaction between banana farmers and local government, village cadres and large-scale farmers (Columns 1-3 in Table 7). Agricultural training in rural China is generally initiated by the local government, and the village committee coordinates with the local government and convenes targeted farmers to conduct the training. The village committee calls in targeted farmers with large farm size, high education levels, and rich planting experience to participate in agricultural training. Hence, banana farmers who have participated in agricultural training interact more frequently with local government, village cadres, and large-scale farmers. Unfortunately, the results present that agricultural training did not increase the interaction range of banana farmers. The interaction range of banana farmers may be more dependent on their own personality characteristics.

After controlling the variable "agricultural training", Equation (3) is used to analyses the mediating effect of the "social interaction". We found that banana farmers' interaction with the local government and the village cadres still significantly impact their adoption of the DFS (Column 7). The banana farmers with a higher frequency of interaction with the village cadres are usually more active in villages. Such farmers may easily access information about newly released policies and agricultural technologies from the village committee. Therefore, farmers who are more active in rural areas may first adopt agricultural innovations such as the DFS. Our empirical results show that farmers' interaction with village cadres could partially mediate the impact of agricultural training on their adoption of the DFS. The proportion of mediating effect in the total effect is about 0.108. Column 1 in Table 5 checked the direct effect of agricultural training on the banana farmers' adoption of the DFS, which showed a coefficient value of 0.726 . "Village cadres" as a mediating variable reduced the effect of agricultural training on the banana farmers' adoption of the DFS from 0.726 to 0.659 (Column 7). The effect of agricultural training on the banana farmers' adoption of the DFS is reduced because 10.8 percent of the effect has transferred through "village cadres". 
Table 7. The mediating effect of farmers' social interaction.

\begin{tabular}{|c|c|c|c|c|c|c|c|}
\hline Variable & $\begin{array}{c}\text { Local } \\
\text { Government } \\
\text { (1) }\end{array}$ & $\underset{(2)}{\text { Village Cadres }}$ & $\begin{array}{l}\text { Large-Scale } \\
\text { Farmers } \\
\text { (3) }\end{array}$ & $\begin{array}{l}\text { Small-Scale } \\
\text { Farmers } \\
(4)\end{array}$ & $\begin{array}{l}\text { Agricultural } \\
\text { Retailers } \\
\text { (5) }\end{array}$ & $\begin{array}{c}\text { Interaction } \\
\text { Range } \\
\text { (6) }\end{array}$ & $\underset{(7)}{\text { Adopt }}$ \\
\hline $\begin{array}{c}\text { Trained } \\
\text { Local } \\
\text { government }\end{array}$ & $0.402(0.093) * * *$ & $0.390(0.098)^{* * *}$ & $0.354(0.104) * * *$ & $0.090(0.074)$ & 0.094(0.095) & $-0.398(4.133)$ & $\begin{array}{c}0.659(0.196)^{* * *} \\
-0.442(0.103) \\
* * *\end{array}$ \\
\hline Village cadres & & & & & & & $0.201(0.095)^{* *}$ \\
\hline $\begin{array}{l}\text { Large-scale } \\
\text { farmers }\end{array}$ & & & & & & & $0.116(0.083)$ \\
\hline $\begin{array}{c}\text { Small-scale } \\
\text { farmers }\end{array}$ & & & & & & & $0.183(0.110) *$ \\
\hline $\begin{array}{l}\text { Agricultural } \\
\text { retailers }\end{array}$ & & & & & & & $0.070(0.084)$ \\
\hline $\begin{array}{l}\text { Interaction } \\
\text { range }\end{array}$ & & & & & & & $0.003(0.003)$ \\
\hline Age & $0.013(0.007) *$ & $0.004(0.007)$ & $-0.002(0.007)$ & $0.003(0.006)$ & $0.016(0.007) *$ & 0.198(0.347) & $0.024(0.014) *$ \\
\hline Gender & $0.175(0.103)$ * & $-0.185(0.118)$ & $0.491(0.123) * * *$ & $-0.004(0.106)$ & $-0.240(0.127)$ * & $8.204(3.023)^{* * *}$ & $-0.141(0.250)$ \\
\hline Education & $0.074(0.015)^{* * *}$ & $0.084(0.015) * * *$ & $0.054(0.017) * * *$ & $0.026(0.014) *$ & $0.042(0.017)^{*}$ & $0.503(0.561)$ & $-0.014(0.032)$ \\
\hline $\begin{array}{l}\text { Planting } \\
\text { experience }\end{array}$ & $-0.005(0.006)$ & $0.006(0.006)$ & $-0.004(0.006)$ & $-0.001(0.005)$ & $-0.008(0.006)$ & $-0.264(0.308)$ & $-\underset{* * *}{0.052(0.012)}$ \\
\hline $\begin{array}{l}\text { Off-farm work } \\
\text { Risk preference }\end{array}$ & $0.136(0.146)$ & $-0.113(0.168)$ & $0.163(0.154)$ & $-0.179(0.130)$ & $-0.077(0.154)$ & $7.517(4.133) *$ & $\begin{array}{l}0.894(0.320)^{* * * *} \\
0.832(0.277)^{* * *}\end{array}$ \\
\hline $\begin{array}{l}\text { Household } \\
\text { income }\end{array}$ & & & & & & & $-0.112(0.099)$ \\
\hline Farm size & $-0.001(0.001)^{* *}$ & $-0.002(0.001)$ & $0.004(0.001)^{* * *}$ & $-0.001(0.000) *$ & $-0.001(0.001)$ & $0.078(0.060)$ & $0.002(0.002)$ \\
\hline $\begin{array}{l}\text { Agricultural } \\
\text { laborers }\end{array}$ & $-0.049(0.041)$ & $-0.023(0.052)$ & $-0.055(0.052)$ & $-0.011(0.037)$ & $-\underset{* * *}{0.138(0.047)}$ & $-1.545(1.210)$ & $-0.196(0.099) * *$ \\
\hline $\begin{array}{l}\text { Agricultural } \\
\text { insurance }\end{array}$ & & & & & & & $-1.197(0.298)$ \\
\hline $\begin{array}{l}\text { Access to } \\
\text { Internet }\end{array}$ & $0.132(0.087)$ & $0.101(0.099)$ & $0.292(0.102) * * *$ & $0.211(0.078)^{* * *}$ & $0.185(0.101) *$ & $-2.680(4.385)$ & \\
\hline Constant & $0.671(0.295) * *$ & $1.841(0.335) * * *$ & $1.713(0.354) * * *$ & $3.590(0.260) * * *$ & $3.231(0.330) * * *$ & 7.044(11.357) & $-0.732(1.282)$ \\
\hline $\begin{array}{l}\text { Pseudo } \\
\text { R-square }\end{array}$ & 0.119 & 0.097 & 0.178 & 0.037 & 0.127 & 0.028 & 0.095 \\
\hline Prob > chi ${ }^{2}$ & 0.000 & 0.000 & 0.000 & 0.002 & 0.000 & 0.000 & 0.000 \\
\hline Observations & 632 & 632 & 632 & 632 & 632 & 632 & 632 \\
\hline
\end{tabular}

Notes: Standard errors are presented in parentheses. ${ }^{* * *} p$ value $<0.01,{ }^{* *} p$ value $<0.05,{ }^{*} p$ value $<0.1$

The coefficient of "local government" is negative and statistically significant (Column 7). This result is contrary to our expectation. We suspect that the farmers rarely interact with the local government in our sample. The villagers committee is the direct governor of the ordinary farmers, so farmers have little opportunity to interact with the local government. We admit that this result requires a further detailed study in these regions. Furthermore, agricultural training did not enhance farmers' interaction with small-scale farmers, but the interaction between them encouraged farmers to increase the adoption rate of the DFS.

\subsection{Active Learning and Banana Farmers' Adoption of the DFS}

The mediating effect model is used to analyze the role of banana farmers' active learning in the relationship between agricultural training and their adoption decisions on the DFS. Firstly, we already know that agricultural training has a positive impact on the banana farmers' adoption of the DFS. Secondly, we have identified the link between agricultural training and the banana farmers' active learning. As shown in Column 1 of Table 8, agricultural training has a significantly positive impact on the banana farmers active learning (at $1 \%$ confidence level). In agricultural training, extension workers may advise farmers to use electronic devices such as smart phones to access agricultural information. After training, smart phones also can be used to look into unclear information left over from training. Additionally, farmers' age, education and off-farm work are also closely related to banana farmers' active learning activities. In rural areas, young farmers may use smart phones more frequently than the elder, so they have a greater possibility to access agricultural information through their smart phones. Farmers with a high education level also have a higher awareness of active learning. Farmers engaged in off-farm work may care more about their non-agricultural work, and they are less likely to actively access agricultural information. 
Table 8. The mediating effect of farmers' active learning.

\begin{tabular}{ccc}
\hline Variable & $\begin{array}{c}\text { Active Learning } \\
\mathbf{( 1 )}\end{array}$ & $\begin{array}{c}\text { Adopt } \\
\mathbf{( 2 )}\end{array}$ \\
\hline Trained & $0.816(0.189)^{* * *}$ & $0.540(0.189)^{* * *}$ \\
Active learning & & $0.546(0.189)^{* * *}$ \\
Age & $-0.033(0.013)^{* * *}$ & $0.024(0.013)^{*}$ \\
Gender & $0.237(0.264)$ & $-0.205(0.243)$ \\
Education & $0.135(0.031)^{* * *}$ & $-0.027(0.031)$ \\
Planting experience & $-0.015(0.012)$ & $-0.047(0.012)^{* * *}$ \\
Off-farm work & $-1.110(0.334)^{* * *}$ & $0.908(0.311)^{* * * *}$ \\
Risk preference & & $0.886(0.268)^{* * *}$ \\
Household income & $0.156(0.966)$ & $-0.102(0.093)$ \\
Agricultural laborers & $0.097(0.085)$ & $-0.208(0.098)^{* *}$ \\
Farm size & $0.003(0.003)$ & $0.002(0.002)$ \\
Agricultural insurance & & $-1.239(0.292)^{* * *}$ \\
Interaction range & $0.001(0.001)$ & $1.467(1.183)$ \\
Constant & $-1.131(1.203)$ & 0.103 \\
Pseudo R-square & 0.138 & 0.00 \\
Prob $>$ chi ${ }^{*}$ & 0.00 & 632 \\
Observations & 632 & $\left.{ }^{*}\right)$ \\
\hline Notes: Standard errors are presented in parentheses. ${ }^{* * *} p$ value $\left.<0.01\right)^{* *} p$ value $<0.05, * p$ value $<0.1$.
\end{tabular}

Thirdly, agricultural training was taken as a control variable, active learning as an independent variable and the banana farmers' adoption of the DFS was used as a dependent variable in the Logistic regression. The results are shown in Column 2, farmers' active learning has a positive impact on their adoption of the DFS after controlling the variable "agricultural training". Combined with the results in Table 5, it can be seen that farmers' active learning activity partially mediates the impact of agricultural training on banana farmers' adoption of the DFS. The proportion of mediating effect in the total effect is about 0.614. In other words, agricultural training not only directly affects the banana farmers' adoption decisions but also improves their adoption rate by strengthening farmers' active learning activities. About 61.4 percent of the impact of agricultural training on farmers' adoption of the DFS is achieved through the mediating role of farmers" "active learning".

\subsection{Treatment of the Endogeneity Problem}

Since the endogeneity problem of agricultural training was not taken into account, the mediating effect test only roughly verified that banana farmers' participation in agricultural training can improve their absorptive capacity of the DFS, extend their social interactions and enhance their active learning. The inference is not accurate enough, so the treatment effect model (TEM) is used to eliminate the endogeneity problem. Table 9 presents that the Wald endogeneity test rejects the null hypothesis that the selection equation and the result equation are independent of each other with significance at the $1 \%$ level. $\rho$ is negative and passes the significance test, indicating the existence of negative selectivity bias. It means that the regression analysis by Equation (1) overestimated the impact of agricultural training on banana farmers' adoption decisions about the use of the DFS.

From the results of the selection equation, we can see that banana farmers with higher education, more planting experience and frequent contact with the local government, village cadres and large-scale farmers have more tendencies to participate in agricultural training (Column 1 in Table 9). This result is basically consistent with the current situation of agricultural training in China's rural areas. As shown in Column 2, compared with those who did not participate in agricultural training, the proportion of the adoption of the DFS by trained farmers was higher, representing that farmers' participation in agricultural training can increase the probability of their adopting the DFS. 
Table 9. The results of the treatment effect model (TEM).

\begin{tabular}{|c|c|c|}
\hline Variable & $\begin{array}{l}\text { Selection Equation } \\
\text { Trained (1) }\end{array}$ & $\begin{array}{c}\text { Results Equation } \\
\text { Adopt (2) }\end{array}$ \\
\hline Age & $-0.002(0.008)$ & $0.006(0.003) *$ \\
\hline Gender & $0.018(0.157)$ & $-0.031(0.056)$ \\
\hline Education & $0.042(0.020)^{* *}$ & $-0.007(0.008)$ \\
\hline Planting experience & $0.012(0.007) *$ & $-0.012(0.003)^{* * *}$ \\
\hline Off-farm work & $0.426(0.178) * *$ & $0.135(0.073) *$ \\
\hline Risk preference & & $0.175(0.055)^{* * *}$ \\
\hline Household income & $0.064(0.060)$ & $-0.037(0.022) *$ \\
\hline Agricultural laborers & $0.069(0.062)$ & $-0.049(0.022)^{* *}$ \\
\hline Farm size & $-0.001(0.001)$ & $0.001(0.001)$ \\
\hline Agricultural insurance & $0.515(0.173)^{* * *}$ & $-0.307(0.075)^{* * *}$ \\
\hline Local government & $0.121(0.058)^{* *}$ & $-0.093(0.024)^{* * *}$ \\
\hline Village cadres & $0.121(0.054)^{* *}$ & \\
\hline Small-scale farmers & $0.007(0.069)$ & $0.046(0.024) * * *$ \\
\hline Large-scale farmers & $0.106(0.050) * *$ & $0.011(0.019)$ \\
\hline Agricultural retailers s & $0.009(0.052)$ & $0.018(0.019)$ \\
\hline Interaction range & $-0.001(0.001)$ & $0.001(0.001)$ * \\
\hline Trained & & $0.467(0.200)^{* *}$ \\
\hline Training needs & $0.743(0.170)^{* * *}$ & \\
\hline Constant & $-3.380(0.791)^{* * *}$ & $0.862(0.289)^{* * *}$ \\
\hline$\rho$ & \multicolumn{2}{|c|}{-0.415} \\
\hline$\sigma$ & \multicolumn{2}{|c|}{0.481} \\
\hline Wald test of indep.eqns. & \multicolumn{2}{|c|}{$2.41^{* * *}$} \\
\hline Log likelihood & \multicolumn{2}{|c|}{-769.269} \\
\hline Observations & 632 & 632 \\
\hline
\end{tabular}

Notes: Standard errors are presented in parentheses. ${ }^{* * *} p<0.01,{ }^{* *} p<0.05,{ }^{*} p<0.1$.

Based on the estimated results of the TEM, we can calculate the average treatment effect (ATE) of agricultural training on the banana farmers' adoption decisions. The results are given in Table 10. The probability of adopting the DFS by trained farmers and nontrained framers is 0.57 and 0.48 , respectively. The ATE of agricultural training on the banana farmers' adoption of the DFS was 0.09 and was significant at the 5\% level. After controlling the possible endogeneity issue, agricultural training increased the adoption rate of banana farmers by 18.75 percent on average level.

Table 10. The average treatment effect of agricultural training on the banana farmers' adoption of the DFS.

\begin{tabular}{|c|c|c|c|c|c|}
\hline & \multicolumn{2}{|c|}{ Agricultural Training } & \multirow{2}{*}{ ATE } & \multirow{2}{*}{$\mathbf{t}$} & \multirow{2}{*}{ Change (\%) } \\
\hline & Trained & Non-Trained & & & \\
\hline Adopt & 0.57 & 0.48 & $0.09^{* *}$ & -2.192 & 18.75 \\
\hline
\end{tabular}

\section{Limitations}

Despite the contribution of our study, the present work also has limitations. First, we did not consider the "trust" variable in agricultural training and the dissemination of knowledge about the DFS. Farmers' trust towards agricultural training technicians or other farmers may affect their absorptive capacities about the knowledge of the DFS and adoption of the DFS. Second, the scarcity of agricultural water in the sample regions may also affect farmers' adoption of the DFS. In regions with shortage of agricultural water resource, farmers may have higher tendency to adopt the DFS, so it may make the promotion of the DFS easier in these regions. Third, other factors, such as agricultural cooperative membership and access to credit may also affect farmers' adoption of the DFS. Considering the impact of the above factors on farmers' knowledge acquisition and adoption of resource-conservation technologies can add value to the present research. 


\section{Conclusions}

The widespread and rapid diffusion of the DFS among banana farmers can increase productivity and lead to the sustainable development of the banana industry; however, its adoption rate remains low in China. There is still a need to facilitate the adoption of the technology among farmers. Agricultural training has been widely implemented in many developing countries as an effective paradigm of spreading innovations in agricultural production. China provides a large budget on technical training at the farmer level every year in order to improve farmers' planting practices and financial performance in rural areas. This study contributes to the existing literature by analyzing the impact of agricultural training on the DFS adoption and exploring the mediating factors in bridging the agricultural training and farmers' adoption decisions, based on the primary data of farmers from main banana producing regions in China.

Three main findings can be drawn from this study. First, agricultural training has a significant and positive impact on banana farmers' adoption decision of the DFS in Southern China. Increased farmers' training experience tends to improve their adoption rate of the DFS. Agricultural training plays an important role in the diffusion of agricultural technologies. In addition, more than 80 percent of banana farmers indicated that it is very necessary to participate in agricultural training. Thus, agricultural training is an effective way for promoting Chinese banana farmers to adopt resource-conservation technologies. Second, at least three types of factors play the mediating role for bridging the agricultural training and farmers' adoption decisions. Agricultural training increased the possibility of banana farmers' adoption of the DFS by improving their active learning, social interaction and absorptive capacity of the DFS in turn. These factors can be given more consideration when agricultural training programs are designed by stakeholders. Third, the impact of agricultural training on banana farmers' adoption of the DFS would be overestimated in existing studies due to the endogeneity problem. However, agricultural training still has a positive impact on the banana farmers' adoption decisions after the endogeneity problem was solved using the TEM. Specifically, agricultural training can increase the probability of banana farmers' adopting the DFS by 18.75 percent.

Our study underscores the importance of agricultural training in the effort to increase the adoption of the DFS among banana farmers in China. Additionally, it provides evidence for the better understanding of the role of agricultural training in promoting resources-conservation technologies in developing countries, and a new perspective for the implementation of agricultural training programs by the government. Farmers' participation in agricultural training can make them better understand advanced farming practices, so their farms may develop in a more sustainable and efficient direction. Based on our findings, the implications for effectively promoting agricultural innovations could be considered. First, to promote wider use of the DFS, policymakers can maximize the effects of agricultural training by selecting target farmers with high educational level and strong active learning. Agricultural training should combine indoor course and field instruction. The timely and wide-reaching indoor course allows farmers to increase their familiarity with recommended new technologies, and also informs them of the risks and uncertainties, economic viability (e.g., cost and benefits) and the DFS applicable conditions (e.g., irrigation water and farm conditions). Intuitive field instruction can help farmers deeply understand the correct operation and economic benefits of the DFS. Second, didactics employed in training could provide an opportunity for farmers to learn from each other, trainers can choose "model farmers" from trained farmers and give them the opportunity to present their successful experiences. Additionally, trainers can set up communication groups for target farmers through social media such as WeChat to speed up direct communication between different farmers and other members. Third, as a convenient channel for farmers' active learning, extension agencies should focus on providing sufficient resources through smart phones to ensure that farmers fully understand the new technology. Similarly, extension technicians may introduce and provide other channels for farmers to solve problems in agricultural cultivation, such as online lectures and agricultural forums. In particular, dur- 
ing the COVID-19 pandemic, online training for farmers can be an alternative method. For example, the government can provide farmers with short video demonstrations through the Internet about sustainable agricultural practices.

Author Contributions: Data Curation, Q.Y.; Formal Analysis, Q.Y.; Funding Acquisition, Y.Z. and F.W.; Investigation, Q.Y., Y.Z. and F.W.; Methodology, Q.Y.; Project Administration, Y.Z. and F.W.; Software, Q.Y.; Supervision, Y.Z.; Visualization, Q.Y.; Writing-Original Draft, Q.Y.; Writing—Review and Editing, Y.Z. and Q.Y. All authors have read and agreed to the published version of the manuscript.

Funding: This research was funded by the National Natural Science Foundation of China, grant number 71863006; Hainan Provincial Natural Science Foundation of China, grant number 720RC581; China Agriculture Research System, grant number CARS-31-14; Research fund of Hainan University, grant number KYQD1615; Innovative Research Project for Postgraduates in Hainan Province in 2019, grant number Hys2019-33. The APC was funded by the National Natural Science Foundation of China, grant number 71863006.

Institutional Review Board Statement: Not applicable.

Informed Consent Statement: Informed consent was obtained from all subjects involved in the study.

Data Availability Statement: Data is contained within the article. Further requests can made to the corresponding author.

Conflicts of Interest: The authors declare no conflict of interest.

\section{References}

1. Sun, B.; Zhang, L.; Yang, L.; Zhang, F.; Norse, D.; Zhu, Z. Agricultural non-point source pollution in China: Causes and mitigation measures. Ambio 2012, 41, 370-379. [CrossRef] [PubMed]

2. Tilman, D.; Fargione, J.; Wolff, B.; D'Antonio, C.; Dobson, A.; Howarth, R.; Schindler, D.; Schlesinger, W.H.; Simberloff, D.; Swackhamer, D. Forecasting agriculturally driven global environmental change. Science 2001, 292, 281-284. [CrossRef] [PubMed]

3. Uphoff, N.; Dazzo, F.B. Making rice production more environmentally-friendly. Environments 2016, 3, 12. [CrossRef]

4. Carter, C.; Zhong, F.; Zhu, J. Advances in Chinese agriculture and its global implications. Appl. Econ. Perspect. Policy 2012, 34, 1-36. [CrossRef]

5. Ngo, H.Q.T.; Huynh, V.N.S.; Nguyen, T.P.; Nguyen, H. Sustainable Agriculture:Stable Robust Control in Presence of Uncertainties for Multi-Functional Indoor Transportation of Farm Products. Agriculture 2020, 10, 523. [CrossRef]

6. Kafkafi, U.; Kant, S. Fertigation. Encycl. Soils Environ. 2005, 1-9. [CrossRef]

7. Sinha, I.; Buttar, G.S.; Brar, A.S. Drip irrigation and fertigation improve economics, water and energy productivity of spring sunflower (Helianthus annuus L.) in Indian Punjab. Agric. Water Manag. 2017, 185, 58-64. [CrossRef]

8. Tian, D.; Zhang, Y.; Mu, Y.; Zhou, Y.; Zhang, C.; Liu, J. The effect of drip irrigation and drip fertigation on $\mathrm{N}_{2} \mathrm{O}$ and $\mathrm{NO}$ emissions, water saving and grain yields in a maize field in the North China Plain. Sci. Total Environ. 2017, 575, 1034-1040. [CrossRef]

9. Sidhu, H.S.; Jat, M.L.; Singh, Y.; Kaur, R.; Gupta, N.; Singh, P.; Asia, S. Sub-surface drip fertigation with conservation agriculture in a rice-wheat system: A breakthrough for addressing water and nitrogen use efficiency. Agric. Water Manag. 2019, 216, 273-283. [CrossRef]

10. Eissa, M.A.; Rekaby, S.A.; Hegab, S.A.; Ragheb, H.M.; Eissa, M.A.; Rekaby, S.A.; Ragheb, H.M. Optimum rate of nitrogen fertilization for drip-irrigated wheat under semi-arid conditions. J. Plant Nutr. 2018, 41, 1414-1424. [CrossRef]

11. Lv, H.; Lin, S.; Wang, Y.; Lian, X.; Zhao, Y.; Li, Y.; Butterbach-bahl, K. Drip fertigation significantly reduces nitrogen leaching in solar greenhouse vegetable production system. Environ. Pollut. 2019, 245, 694-701. [CrossRef]

12. Zornoza, R.; Rosales, R.; Acosta, J.A.; de la Rosa, J.M.; Arcenegui, V.; Faz, Á.; Pérez-Pastor, A. Geoderma Ef Fi Cient Irrigation Management Can Contribute to Reduce Soil $\mathrm{CO}_{2}$ Emissions in Agriculture. Geoderma 2016, 263, 70-77. [CrossRef]

13. Zornoza, R.; Acosta, J.A.; Gabarrón, M.; Gómez-Garrido, M.; Sánchez-Navarro, V.; Terrero, A.; Martínez-Martínez, S.; Faz, Á.; Pérez-Pastor, A. Science of the Total Environment Greenhouse Gas Emissions and Soil Organic Matter Dynamics in Woody Crop Orchards with Different Irrigation Regimes. Sci. Total Environ. 2018, 644, 1429-1438. [CrossRef]

14. Jin, S.; Bluemling, B.; Mol, A.P. Information, trust and pesticide overuse: Interactions between retailers and cotton farmers in China. NJAS-Wagen. J. Life Sci. 2015, 72, 23-32. [CrossRef]

15. Rogers, E.M. Evolution: Diffusion of Innovations. International Encyclopedia of the Social \& Behavioral Sciences; Pergamon: Oxford, UK, 2001; Volume 7, pp. 4982-4986. [CrossRef]

16. Ma, W.; Zhou, X.; Renwick, A. Impact of off-farm income on household energy expenditures in China: Implications for rural energy transition. Energy Policy 2019, 127, 248-258. [CrossRef]

17. Tate, G.; Mbzibain, A.; Ali, S. A comparison of the drivers influencing farmers' adoption of enterprises associated with renewable energy. Energy Policy 2012, 49, 400-409. [CrossRef] 
18. Adnan, N.; Nordin, S.M.; Ali, M. A solution for the sunset industry: Adoption of Green Fertiliser Technology amongst Malaysian paddy farmers. Land Use Policy. 2018, 79, 575-584. [CrossRef]

19. Souza, A.; Mishra, A.K. Adoption and Abandonment of Partial Conservation Technologies in Developing Economies: The Case of South Asia. Land Use Policy 2018, 70, 212-223. [CrossRef]

20. Zhang, Z.; Mu, Y.; Hou, L.; Yang, X. Resource and economic effects of drip irrigation in the Bohai Rim area: Consistency of goals of the government and farmers. Resour. Sci. 2019, 41, 1400-1415. [CrossRef]

21. Dalemans, F.; Muys, B.; Maertens, M. Adoption Constraints for Small-scale Agroforestry-based Biofuel Systems in India. Ecol. Econ. 2019, 157, 27-39. [CrossRef]

22. Coromaldi, M.; Pallante, G.; Savastano, S. Adoption of modern varieties, farmers' welfare and crop biodiversity: Evidence from Uganda. Ecol. Econ. 2015, 119, 346-358. [CrossRef]

23. Xu, H.; Huang, X.; Zhong, T.; Chen, Z.; Yu, J. Chinese land policies and farmers' adoption of organic fertilizer for saline soils. Land Use Policy 2014, 38, 541-549. [CrossRef]

24. Ji, C.; Jin, S.; Wang, H.; Ye, C. Estimating effects of cooperative membership on farmers' safe production behaviors: Evidence from pig sector in China. Food Policy 2019, 83, 231-245. [CrossRef]

25. Yigezu, Y.A.; Mugera, A.; El-Shater, T.; Aw-Hassan, A.; Piggin, C.; Haddad, A.; Khalil, Y.; Loss, S. Enhancing adoption of agricultural technologies requiring high initial investment among smallholders. Technol. Forecast. Soc. Chang. 2018, 134, $199-206$. [CrossRef]

26. Zhang, S.; Sun, Z.; Ma, W.; Valentinov, V. The effect of cooperative membership on agricultural technology adoption in Sichuan, China. China Econ. Rev. 2020, 62, 101334. [CrossRef]

27. Nakano, Y.; Tsusaka, T.W.; Aida, T.; Pede, V.O. Is farmer-to-farmer extension effective ? The impact of training on technology adoption and rice farming productivity in Tanzania. World Dev. 2018, 105, 336-351. [CrossRef]

28. Blazy, J.; Paul, J.; Sierra, J.; Causeret, F.; Guind, L. Factors affecting the adoption of compost use by farmers in small tropical Caribbean islands. J. Clean. Prod. 2017, 142, 1387-1396. [CrossRef]

29. Ramirez, A. The Influence of Social Networks on Agricultural Technology Adoption. Procedia Soc. Behav. Sci. 2013, 79, 101-116. [CrossRef]

30. Abbas, T.; Ali, G.; Adil, S.A.; Bashir, M.K.; Kamran, M.A. Economic analysis of biogas adoption technology by rural farmers: The case of Faisalabad district in Pakistan. Renew. Energy 2017, 107, 431-439. [CrossRef]

31. Roman, M.; Roman, M.; Prus, P.; Szczepanek, M. Tourism Competitiveness of Rural Areas: Evidence from a Region in Poland. Agriculture 2020, 10, 569. [CrossRef]

32. Liu, Y.; Ruiz-menjivar, J.; Zhang, L.; Zhang, J.; Swisher, M.E. Technical training and rice farmers' adoption of low-carbon management practices: The case of soil testing and formulated fertilization technologies in Hubei, China. J. Clean. Prod. 2019, 226, 454-462. [CrossRef]

33. Zhang, T.; Yang, Y.; Ni, J.; Xie, D. Adoption behavior of cleaner production techniques to control agricultural non-point source pollution: A case study in the Three Gorges Reservoir Area. J. Clean. Prod. 2019, 223, 897-906. [CrossRef]

34. Sambodo, L.A. The Decision Making Processes of Semi-commercial Farmers: A Case Study of Technology Adoption in Indonesia. Ph.D. Thesis, Lincoln University, Lincoln, New Zealand, 2007.

35. Tey, Y.S. The Adoption of Sustainable Agricultural Practices: An Integrative Approach for Malaysian Vegetable Farmers. Ph.D. Thesis, The University of Adelaide, Adelaide, Australia, 2013.

36. Pan, D.; Zhang, N. The Role of Agricultural Training on Fertilizer Use Knowledge: A Randomized Controlled Experiment. Ecol. Econ. 2018, 148, 77-91. [CrossRef]

37. Vishnu, S.; Gupta, J.; Subash, S.P. Social network structures among the livestock farmers vis a vis calcium supplement technology. IPA 2019, 6, 170-182. [CrossRef]

38. Hunecke, C.; Engler, A.; Jara-Rojas, R.; Poortvliet, P.M. Understanding the role of social capital in adoption decisions: An application to irrigation technology. Agric. Syst. 2017, 153, 221-231. [CrossRef]

39. Shikuku, K.M. Information exchange links, knowledge exposure, and adoption of agricultural technologies in northern Uganda. World Dev. 2019, 115, 94-106. [CrossRef]

40. Gars, J.; Ward, P.S. Can differences in individual learning explain patterns of technology adoption? Evidence on heterogeneous learning patterns and hybrid rice adoption in Bihar, India. World Dev. 2019, 115, 178-189. [CrossRef]

41. Barham, B.L.; Chavas, J.-P.; Fitz, D.; Rios-Salas, V.; Schechter, L. Risk, learning, and technology adoption. Agric. Econ. 2015, 46, 11-24. [CrossRef]

42. Mackinnon, D. Introduction to Statistical Mediation Analysis; Earlbaum: Mahwah, NJ, USA, 2008.

43. Fairchild, A.J.; Mackinnon, D.P. A General Model for Testing Mediation and Moderation Effects. Prev. Sci. 2009, 10, 87-99. [CrossRef]

44. Baron, R.M.; Kenny, D.A. The moderator-mediator variable distinction in social psychological research: Conceptual, strategic, and statistical considerations. J. Pers. Soc. Psychol. 1986, 51, 1173-1182. [CrossRef]

45. Judd, C.M.; Kenny, D.A. Process analysis: Estimating mediation in treatment evaluations. Eval. Rev. 1981, 5, 602-619. [CrossRef]

46. Hayes, A.F. Beyond Baron and Kenny: Statistical mediation analysis in the new millennium. Commun. Monogr. 2009, 76, 408-420. [CrossRef] 